\title{
Cost of pruning Douglas-fir in coastal British Columbia
}

\author{
by S.A.Y. Omule ${ }^{1}$, D.E. Paul ${ }^{2}$, and L.M. Darling ${ }^{3}$
}

Artificial pruning can increase the quantity of high-value clear lumber harvested from Douglas-fir, but the pruning cost per tree is relatively high. To prune a young Douglas-fir to 6 metres in one lift and two lifts took, respectively, 9.5 and 10.1 minutes in 14- and 18-year old stands with average spacing between trees of about 3 metres on flat or $0-30 \%$ south-facing slopes in coastal British Columbia. The associated costs were $\$ 2.09$ and $\$ 2.22$. This included minor travel time between trees, but excluded the cost of travelling to the site, selecting and marking trees to be pruned, and purchasing and maintaining the pruning equipment. Differences in pruning time between one-lift pruning and two-lift pruning, in one or two passes, were small. A D-handled saw was preferred to the more strenuous snap-cut pruner with ratchet-style pinions, based on observations on a pruning time-study of 5 operators.

Key words: pruning saw, snap-cut pruner, pruning time, onelift pruning, two-lift pruning
L'élagage artificiel peut accroître la quantité récoltée de bois de sciage de sapin de Douglas en qualité et en prix, mais les coûts d'élagage par arbre sont élevés. L'élagage d'un jeune sapin de Douglas jusqu'à 6 mètres de hauteur en une seule et en deux étapes nécessite, respectivement, 9.5 et 10.1 minutes dans des peuplements de 14 à 18 ans dont l'espacement moyen entre les arbres est d'environ 3 mètres sur un terrain plat ou ayant une pente de $0-30 \%$ orientée vers le sud dans la région côtière de la Colombie-Britannique. Les coûts associés à cette opération sont de $2.09 \$$ et $2.22 \$$. Ces coûts comprennent les courts temps de déplacement entre les arbres, mais excluent les coûts de transport jusqu'au site, de sélection et de marquage des arbres à élaguer, d'achat et d'entretien de l'équipement d'élagage. Les différences des temps d'élagage entre les opérations en une seule et en deux étapes sont minimes. La scie à poignée en $\mathrm{D}$ a été préférée au sécateur à rochet à action éclair très exigeant, selon les observations effectuées à partir d'étude de temps d'élagage de 5 opérateurs.

Mots clés: scie d'élagage, sécateur à action éclair, temps d'élagage, élagage en une étape, élagage en deux étapes

\section{Introduction}

Artificial pruning is necessary for the production of clear lumber in acceptable rotations for Douglas-fir which typically retains its dead branches for decades (Smith 1962), but the cost per tree of pruning is high relative to that of most other silviculture operations. Published costs of pruning Douglas-fir are scanty with time estimates ranging from about $2 \mathrm{~min} /$ tree to about $25 \mathrm{~min} /$ tree, depending on tree age, height of pruning, terrain, stand density, branch number and size, and type of equipment used (Shaw and Staebler 1950; Stein 1955; Dobie and Wright 1978; Fight et al. 1988).

Pruning has not been used widely in British Columbia, presumably because of the relatively high pruning cost per tree and relative abundance of clear wood from old-growth forests. Only about 2,600 ha of coastal Douglas-fir (Pseudotsuga menziesii [Mirb.] Franco) have been pruned to date; most were pruned in the early 1980 s as part of federal job-creation programs. However, pruning is now of increasing interest to British Columbia's forest managers because of the declining supply of clear wood as harvesting shifts from old-growth forests to second-growth forests.

Results of a time study on pruning young Douglas-fir are presented here. The results can be helpful to forest managers who must decide how and when to prune a given stand. As well, this study's pruning cost estimates can be

\footnotetext{
${ }^{1}$ BC Ministry of Forests, Inventory Branch, 1319 Government Street, Victoria, BC V8W 3E7.

${ }^{2}$ BC Ministry of Forests, Research Branch, 506 - 1175 Douglas Street, Victoria, BC V8W 3E7.

${ }^{3}$ BC Environment, Wildlife Branch, 780 Blanshard Street, Victoria, BC V8V 1 X5
}

included in modelling systems (e.g., SYLVER (Mitchell, Kellogg and Polsson 1989)) to facilitate analyses of financial returns for pruning. The study compared the time required for one-pass pruning and two-pass pruning, and for one-lift pruning and two-lift pruning, using a saw and a pruner. Lift refers to the raising of the base of a tree's live crown, in this case artificially by pruning; pass refers to the total number of times an operator goes through the stand in the same field season to accomplish a lift.

\section{Methods}

\section{Study Area}

Two thinned Douglas-fir stands, aged 14 and 18 years, located in the Cowichan Valley of Vancouver Island, were the basis of study. Stand density was $900-1,100$ stems/ha, and average spacing between trees was $3.0-3.3 \mathrm{~m}$ in both stands. Average tree diameters were $8 \mathrm{~cm}$ and $20 \mathrm{~cm}$ in the 14-year-old and 18-year-old stands respectively. The 14year-old stand was more uniform in height and diameter than the 18-year-old stand (Figure 1). Site index was about $40 \mathrm{~m}$ at 50 years breast-height age in the 14-year-old stand, and ranged from 25 to $29 \mathrm{~m}$ in the 18-year-old stand, based on Bruce's (1981) site curves. The 14-year-old stand was located on a $0-30 \%$ south-facing slope at an elevation of $220 \mathrm{~m}$ above sea level. Two locations were selected subjectively in the 14-year-old stand and three in the 18-yearold stand. Each site contained 150 trees which were tagged. There was little or no underbrush in the stands and the thinnings left on-site 6 years previously did not impede operator movement.

The weather during the study period of treatment (13 16 March 1989$)$ was mainly cool $\left(5^{\circ} \mathrm{C}\right)$ and cloudy, with sunny breaks; there was drizzle one day, and showers with intermittent snow on the last day. 


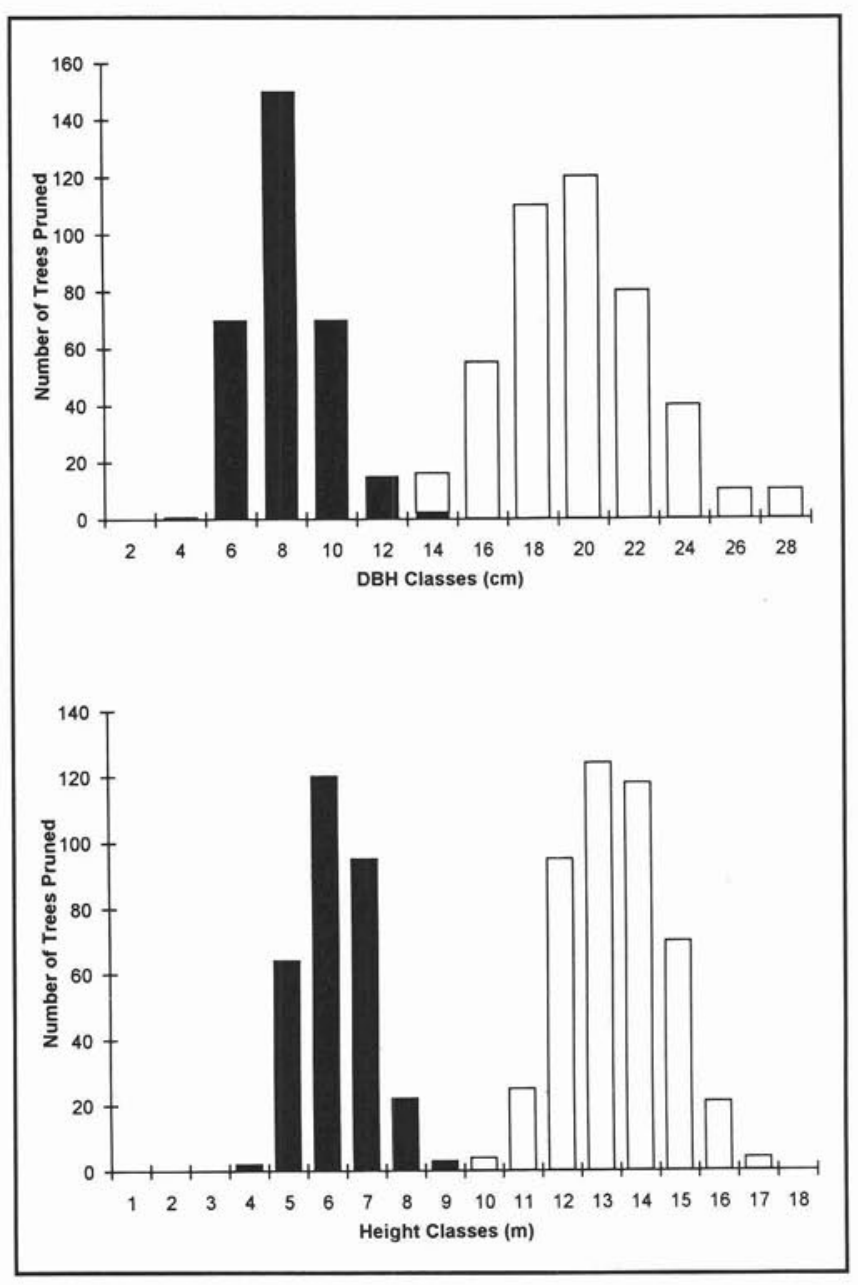

Figure 1. Diameter and height distributions for two Douglas-fir stands in the Cowichan Valley of Vancouver Island, BC $\square$, 18-year-old stands; $\mathbf{\square}$, 14-year-old stands.

\section{Approach}

The variable of interest was the time needed to prune each tree, including travel time between trees. Neither the time to travel to the site nor the cost of marking the stand for pruning was considered.

Operators were contract crews with variable pruning experiences. They received two hours of office and field training, during which they were made aware of the study objectives and procedures. The crews gained experience by pruning adjacent stands, prior to actual timing. An experienced supervisor was present to ensure compliance with the required pruning, timing and measurement standards.

Pruning treatments were defined by a combination of height of lift, number of pruning passes, and type of pruning tools. Two pruning tools were used: (i) a D-handled saw along with a one-piece, 2- to 3-m long ladder, with foam rubber wrapped around its uprights and rope looped around its top rungs to access higher branches, and (ii) a snap-cut pruner with ratchet style pinions. The pruning treatments were: (A) a 6-m lift in one pass with a saw and ladder, (B) a 6-m lift in two passes, one with a saw and the other with a saw and ladder, (C) a 6-m lift in two passes, one with a pruner and the other with a saw and ladder, (D) a 3-m lift in one pass with a saw, and (E) a 3-m lift in one pass with pruners (Table 1). The first passes of treatments $\mathrm{B}$ and $\mathrm{C}$ were identified as treatments $\mathrm{P}$ and $\mathrm{Q}$, respectively. As well, pruning treatments $\mathrm{G}$ and $\mathrm{H}$ that mimic a 6-m lift in 2 passes were simulated because we did not wait 4 years or find a suitable stand that was previously pruned. Treatment $G$ was a combination of treatment $D$ and the second pass of treatment $\mathrm{B}$; treatment $\mathrm{H}$ was a combination of treatment $\mathrm{E}$ and the second pass of treatment $\mathrm{C}$. That is, trees used for the $0-3 \mathrm{~m}$ lift at age 14 years were different from those used for 3-6 m lift at age 18 years.

Operators were each assigned 30 trees on each of 5 sites in the 14- and 18-year-old stands. Individuals were timed by a person who also recorded tree measurements before and after pruning. The times recorded were pruning time, travel time to the next tree, and idle time. Tree measurements taken before pruning were dbh, total height and total number of whorls in each tree, and number of branches per whorl, number of internodla whorls, and branch diameters of a random sample of whorls and branches. The number of whorls remaining on each tree and the height to the lowest remaining whorl measured were recorded after pruning.

Treatment means of pruning time and pruning-plus-travel time, calculated from data subsets appropriate to each study objective were adjusted and compared based on oneand two-way analyses of covariance. Treatment means were separated using Tukey's test, when the treatment effects were significant $(P<0.05)$. The covariates considered for inclusion were the measured or estimated individual-tree attributes: $\mathrm{dbh}$, total height, mean branch diameter per tree and per site, actual pruning height, total number of whorls per tree, and mean number of whorls cut per tree. The total number of branches per whorl and mean branch diameters were estimated based on sample observations and relationships.

\section{Results and Discussions \\ Pruning Time}

The average pruning, pruning-plus-travel, and idle times are shown by treatment (Table 1). The treatment comparisons based on pruning time were similar to those based on pruning-plus-travel time. Thus the rest of the discussion will focus on pruning-plus-travel time only.

\section{Number of Passes}

Differences in mean pruning-plus-travel time between a 6-m lift in one pass, (treatment $\mathrm{A}$ ) and a $6 \mathrm{~m}$ lift in twopasses, (treatments B and C) in the 18-year-old stand were small (Table 1). The pruning-plus-travel time, averaged over the three treatments, was $9.5 \mathrm{~min} /$ tree. The two most efficient operators in the study attained an average pruning-plus-travel time of about $6 \mathrm{~min} /$ tree. This suggests that using efficient operators and pruning tools could reduce the pruning-plus-travel time in the study by about onethird. The covariates dbh, total height and mean branch diameter were statistically significant, demonstrating that tree and branch size affected productivity. Pruning time increased with increases in tree dbh, total height and branch diameter. At a contract wage of $\$ 13 / \mathrm{h}$, the cost of pruning, including travel time between trees, was $\$ 2.09 /$ tree. This cost excluded,other costs, such as the cost of selecting 
Table 1. Mean pruning-plus-travel times for each treatment

\begin{tabular}{|c|c|c|c|c|c|c|c|c|c|}
\hline Treatment $^{1}$ & $\begin{array}{c}\text { Lift } \\
\text { height } \\
(\mathrm{m})\end{array}$ & $\begin{array}{c}\text { No. } \\
\text { passes }\end{array}$ & Equipment & $\begin{array}{l}\text { Stand age } \\
\text { (years) }\end{array}$ & $\begin{array}{c}\text { No. } \\
\text { operators }\end{array}$ & $\begin{array}{l}\text { No. } \\
\text { trees }\end{array}$ & $\begin{array}{l}\text { Mean idle } \\
\text { time } \\
\text { (min/tree) }\end{array}$ & $\begin{array}{l}\text { Mean time } \\
\text { Pruning }\end{array}$ & $\begin{array}{l}\text { (min/tree) } \\
\text { Pruning \& } \\
\text { travelling }\end{array}$ \\
\hline A & 6 & 1 & Saw \& ladder & 18 & 3 & 90 & 1.11 & 9.2 & 9.5 \\
\hline B & $3 / 6$ & 2 & Saw/saw \& ladder & 18 & 3 & 89 & 0.47 & 8.7 & 9.2 \\
\hline $\mathrm{C}$ & $3 / 6$ & 2 & Pruners/saw \& ladder & 18 & 4 & 120 & 0.67 & 9.2 & 9.8 \\
\hline D & 3 & 1 & Saw & 14 & 5 & 150 & 0.05 & 2.4 & 2.6 \\
\hline $\mathrm{E}$ & 3 & 1 & Pruners & 14 & 4 & 150 & 0.05 & 3.4 & 3.5 \\
\hline$P$ & 3 & 1 & Saw & 18 & 3 & 89 & 0.10 & 2.5 & 2.7 \\
\hline Q & 3 & 1 & Pruners & 18 & 4 & 120 & 0.22 & 2.6 & 2.7 \\
\hline G & $3 / 6$ & 2 & Saw/saw \& ladder & 14,18 & 4 & & & 9.3 & 9.9 \\
\hline $\mathrm{H}$ & $3 / 6$ & 2 & Pruners/saw \& ladder & 14,18 & 3 & & & 9.8 & 10.3 \\
\hline
\end{tabular}

1. Treatment definitions:

$\mathrm{A}$ is a 6-metre lift in one pass with a saw and ladder.

$\mathrm{B}$ is a 6-metre lift in two 3-metre passes, one with a saw and the other with a saw and ladder.

$\mathrm{C}$ is a 6-metre lift in two 3-metre passes, one with a pruner and the other with a saw and ladder.

$\mathrm{D}$ is a 3 -metre lift in one pass with a saw.

$\mathrm{E}$ is a 3-metre lift in one pass with a pruner.

$\mathrm{P}$ is the $0-3$ metre pass of treatment $\mathrm{B}$.

$\mathrm{Q}$ is the $0-3$ metre pass of treatment $\mathrm{C}$.

$\mathrm{G}$ is the combination of treatment $\mathrm{D}$ and the 3-6 metre pass of treatment $\mathrm{B}$.

$\mathrm{H}$ is the combination of treatment $\mathrm{E}$ and the 3-6 metre pass of treatment $\mathrm{C}$.

and marking trees to prune, travelling to the pruning site and purchasing and maintaining equipment, which could more than double the pruning cost.

The practical implication is that forest managers have flexibility in organizing a pruning crew because there are no real differences in pruning time between one-pass pruning and two-pass pruning. However, other factors such as safety, travel time between trees and other logistics may limit the choice of pruning method. Travel time between trees may be significant in widely spaced stands where pruning is of higher priority.

\section{Number of Lifts}

Differences in mean pruning-plus-travel time between one-lift pruning at age 18 years (treatment $\mathrm{A}$ ) and two-lift pruning at ages 14 and 18 years (treatments $\mathrm{G}$ and $\mathrm{H}$ ) were also small (Table 1). The pruning-plus-travel time for twolift pruning, averaged over the two treatments, was 10.01 $\mathrm{min} /$ tree. These results were not based on the same trees at each lift. It is possible that 4 years after the first lift, the branches in the pruned trees would be bigger than those in the unpruned trees of the same age. This would affect the pruning time. Differences may arise when fixed costs (e.g., cost of travelling to pruning site), and compound interest on costs incurred on the first of two lifts, are taken into account. Thus, while there are no differences in pruning time between one-lift and two-lift pruning, the two-lift pruning may be more costly than the one-lift pruning because of the differences in tree size and the fixed costs. However, to achieve a smaller knotty core and a greater yield of clear lumber, the two-lift pruning would be preferred. Current practices in other countries such as New Zealand favours two-or even three-lift pruning.

\section{Pruning Tools}

Differences in mean pruning-plus-travel time between the saw and the pruner in a 3-m lift pruning in both the 14- year-old stand (treatments D and E) and the 18-year-old stand (treatments P and Q) were small (Table 1). The mean pruning-plus-travel time in the 14-year-old stand, averaged over the two treatments, was $3.1 \mathrm{~min} /$ tree. The mean pruning-plus-travel time in the 18 -year-old stand, averaged over the two treatments, was $2.7 \mathrm{~min} /$ tree.

Differences between the two tools were more pronounced in the 14-year-old stand than in the 18-year-old stand. It also appears that the pruners were quicker in the 18-year-old stands than in the 14-year-old stands (Table 1). This is possibly explained by the observation that operators improved efficiency by using the pruner as a club to knock off dead and dying branches. But the clubbing left poorer quality stubs. Most operators preferred the D-handled saw to the snap-cut pruner because the saw was easier to handle and less strenuous.

\section{Idle Time}

Average idle time per tree was generally minor, but important in the 6-metre one-pass (Table 1). It was highly dependent on the physical condition and experience of the operators. The average idle time per operator ranged from 0.2 to $1.5 \mathrm{~min} /$ tree. It was common for operators to rest before moving on to the next tree.

\section{Conclusions}

The following general conclusions were made from the study:

- Differences in pruning time between a 6-m lift in onepass and a 6-m lift in two passes, at age 18 years were small. On the average, it took $9.5 \mathrm{~min} /$ tree to conduct a 6-m lift in one or two passes at this age.

- Differences in pruning time between a one 6-m lift at age 18 years and two $3-\mathrm{m}$ lifts at ages 14 and 18 years were also small. On the average, it took $10.1 \mathrm{~min} /$ tree to conduct two 3-m lifts at these ages. 
- The saw, compared with the pruner, was faster in the 14year-old stand (but not significantly so) and was preferred by operators.

\section{Acknowledgements}

The funds for this research project were provided by the Canada/British Columbia Forest Resource Development Agreement - a five-year (1985-1990) \$300 million program costshared equally by the federal and provincial governments. We thank Canadian Pacific Forest Products Limited for assisting with the study; Dr. Kenneth Mitchell for suggesting this study and reviewing the draft manuscript; Dr. James Thrower and $\mathrm{Mr}$. Miklos Kovats for reviewing the draft manuscript; and the anonymous referees for their valuable comments.

\section{References}

Bruce, D. 1981. Consistent height-growth and growth-rate esti- mates from remeasured plots. For. Sci. 27(4): 711-725.

Dobie, J. and D.M. Wright. 1978. Economics of thinning and pruning - a case study. For. Chron. 54(1): 34-38.

Fight, R.D., J.M. Cahill, T.D. Fahey and T.A. Snellgrove. 1988. A new look at pruning coast Douglas-fir. W.J. Appl. For. 3(2): 46-48.

Mitchell, K.J., R.M. Kellogg and K.R. Polsson. 1989. SYLVER: The link between silvicultural practices and financial return. Canadian Pulp and Paper Association, Woodlands Section annual meeting, Montreal, March 1989.

SAS Institute, Inc. 1987. SAS user's guide: statistics, Version 5 edition. SAS Institute, Inc., Box 8000, Cary, NC 27511-8000.

Shaw, E.W. and G.R. Staebler. 1950. Financial aspects of pruning. USDA For. Serv. Pac. NW For. and Range Exp. Sta., Portland, Ore. Typewritten Report, 45 p.

Smith, D.M. 1962. The practice of silviculture. Seventh edition. John Wiley \& Sons, Inc., New York. 131 p.

Stein, W.I. 1955. Pruning to different heights in young Douglasfir. J. For. 53(5): 352-355.

\section{Change of Address}

Date Section

Surname first - no titles

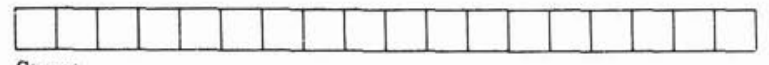

\section{Street}

\section{City and Province}

Postal Code

\section{Changement d'adresse}

Date Section

Prénom en avant - pas de titres
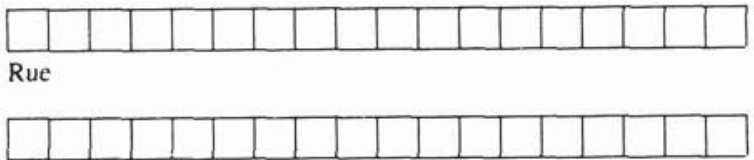

Ville et Province

Code Postale 